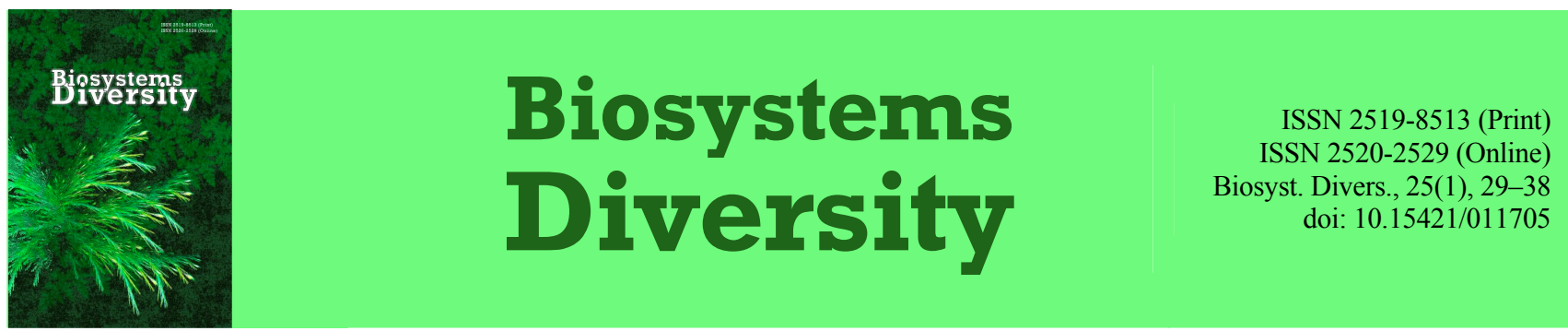

\title{
Structure of litter macrofauna communities in poplar plantations in an urban ecosystem in Ukraine
}

\author{
L. I. Faly*, T. M. Kolombar*, E. V. Prokopenko**, O. Y. Pakhomov*, V. V. Brygadyrenko* \\ * Oles Honchar Dnipropetrovsk National University, Dnipro, Ukraine \\ **Donetsk National University, Donetsk, Ukraine
}

Article info

Received 18.12.2016

Received in revised form 03.03 .2017

Accepted 05.03.2017

Oles Honchar Dnipropetrovsk National University

Gagarin ave., 72 ,

Dnipro, 49010, Ukraine

E-mail:brigad@uafm

Donetsk National University

Shhorsa str., 46,

Donetsk, 83050, Ukraine
Faly, L. I., Kolombar, T. M., Prokopenko, E. V., Pakhomov, O. Y., \& Brygadyrenko, V. V. (2017). Structure of litter macrofauna communities in poplar plantations in an urban ecosystem in Ukraine. Biosystems Diversity, 25(1), 29-38. doi: $10.15421 / 011705$

The litter macrofauna of 8 plantations of Populus italica (Du Roi) Moench, P. deltoides Marsh. and P. alba L. was studied in the city of Dnipro. The invertebrates were taken by manual sifting of litter from experimental plots of $8 \mathrm{~m}^{2}$. The total number of litter macrofauna in the poplar plantations varied from 8 to $187 \mathrm{specimen} / \mathrm{m}^{2}$, on average $53 \mathrm{specimen} / \mathrm{m}^{2}$. The greatest variety of species was obtained from a white poplar plantation with common hop and an elm-poplar plantation with bare soil and Amorpha fruticosa L. bushes (15 and 9 species correspondingly). The maximum readings on the Shannon-Weaver diversity index come from the abovementioned areas (3.2 and 2.9 bits respectively). The highest number of zoophages ( $40 \%$ ) was obtained from the white poplar plantation with common hop. There was great consistency in the species composition across the plots, with the same 60 species (more than $50 \%$ of the total number of species of litter macrofauna recorded in the study) being found in 7 out of the 8 study plots. The share of species rare for any given ecosystem exceeded $10 \%$ in only 2 out of the 8 plantations studied. The dominant group in the size structure of the litter macrofauna of the poplar plantations (44-96\%) was invertebrates of 4-7 mm length. In 5 out of 8 poplar plantations no species over $15 \mathrm{~mm}$ in length were found. This indicates the degraded size structures of the litter macrofauna communities. In taxonomic structure the dominant groups were Formicidae, Pulmonata, Porcellionidae, Lygaeidae, Julidae, Silphidae, Araneae, Carabidae, Staphylinidae. The results obtained indicate the low variety and degradation of the trophic and size structure of the litter macrofauna of these urban poplar plantations, which are subject to lack of moisture.

Keywords: forest ecosystems; biological diversity; litter invertebrates; dominance structure; trophic structure; size structure

\section{Introduction}

Variability in the share of species and their ecological groups in community structures is most obvious in ecosystems under heavy anthropogenic pressure (Pearce and Venier, 2006; Spitzer et al., 2008). Many regions of Central and Eastern Ukraine are located in a zone of ecological impoverishment. A large part of this territory is affected by the intensive influence of agriculture, coal mining and the metallurgical industry (Faly and Brygadyrenko, 2014; Kul'bachko et al., 2015). Plantation forests and shelterbelts form a major part of South Ukraine's forest vegetation. In urban environments they are subject to heavy technogenic pressure (Moroz et al., 2011; Brygadyrenko and Ivanyshin, 2014). The dominant tree species in forest belts of the steppe zone are planted Robinia pseudoacacia L. and Fraxinus excelsior L. In urban landscapes, apart from the abovementioned species, plantations of Populus pyramidalis Borkh., P. alba L., P. tremula L. are widespread (Brygadyrenko, 2014, 2015c).

Earlier, we studied litter invertebrate communities in forest plantations of Ukraine's steppe zone, the peculiarities of the size, trophic and taxonomical structures of their communities (Brygadyrenko, 2015a, 2015b, 2016a). The distribution of an animal population within the litter horizon is regulated by many factors. The most significant are a mixture of phytocenosis, humidity, soil texture and litter capacity (Brygadyrenko, 2015a, 2015b, 2015c, 2016b). In urban forest plantations, a specific community composition develops which is very different from those of natural forest ecosystems (Moroz et al., 2011). In general, the species composition of urban landscapes is impoverished, being formed from ubiquitous species that are not specia- lized in their feeding and habitat requirements (Faly and Brygadyrenko, 2014). Many litter invertebrates react to even insignificant negative changes in their habitat by decreasing in number (Cameron and Leather, 2012). In this connection, the question arises of using dominant groups of invertebrates in zoological diagnostics of transformation processes in urbanized ecosystems in Ukraine's steppe zone (Moroz et al., 2011). Detailed studies of the basic characteristics of litter invertebrates allow the most vulnerable species of invertebrates in need of protection to be identified. Complex analysis of the litter macrofauna of urban landscapes is represented in the literature covering soil-zoology (Slipinski et al., 2012). Often the authors restrict themselves to counting the species present or the total number of invertebrates. However, apart from abundance it is also important to analyse the share taken by separate trophic, size and taxonomic groups (Oxbrough et al., 2005; Brygadyrenko, 2014).

The objective of this article is to provide a description of the structure of litter invertebrate communities in poplar plantations in a large city, based on the example of Dnipropetrovsk.

\section{Materials and methods}

Collection was carried out in August of 2013 in the city of Dnipro (Central Ukraine). In the studied types of artificial plantations the dominant species were Populus italica (Du Roi) Moench, P. deltoides Marsh. and $P$. alba L. (Table 1). The age of the plantations was about 60-65 years. For the count of invertebrates the method of manual sifting of litter was used. On each of the 8 study plots the sampling of invertebrates was made from 8 subplots, each $1 \times 1 \mathrm{~m}$. The selected plots 
varied in litter volume, number of plant species and density of the herbaceous layer, percentage of cover of each tree and shrub species at the juvenile and immature stages of development. Before collecting the macrofauna, a description of the vegetation cover was made with measurements (\%) for the cover of every species of herbaceous plant, bush and tree. For collecting the invertebrates from each $1 \mathrm{~m}^{2}$ plot, we collected litter, put it through a soil sieve $(60 \times 60 \mathrm{~cm}$, mesh diameter $-2 \mathrm{~cm})$ and sifted it onto a polyethylene sheet. After sifting, the coarse and fine fragments of plant remains were examined for invertebrates. For the assessment of the diversity of the litter macrofauna we used the most wellknown indexes Shannon-Weaver (Shannon and Weaver, 1949; Pielou, 1977). The statistical analysis of the results was performed through a set of Statistica 8.0 programmes (StatSoft Inc., USA), on the diagrams is shown the median, $25 \%$ and $75 \%$ quartiles, minimum and maximum values.

Table 1

Brief characteristics of the studied poplar plantations

\begin{tabular}{|c|c|c|c|c|c|}
\hline No & Type of plantation & $\begin{array}{l}\text { Moisture } \\
\text { conditions }\end{array}$ & $\begin{array}{c}\text { Density } \\
\text { of tree crown layer, } \%\end{array}$ & $\begin{array}{l}\text { Density of bush, liana } \\
\text { and sapling layer, } \%\end{array}$ & Density of herbaceous layer, $\%$ \\
\hline 1 & $\begin{array}{l}\text { Sycamore poplar } \\
\text { plantation with } \\
\text { Virginia creeper }\end{array}$ & mesohygrophilous & $\begin{array}{l}95 \text { (Populus italica (Du Roi) } \\
\text { Moench - 70, Ulmus carpinifolia } \\
\text { Rupp. ex G. Suckow - 15, } \\
\text { Acer platanoides L. - 10) }\end{array}$ & $\begin{array}{l}95 \text { (Parthenocissus } \\
\text { quinquefolia } \text { Planch.) }\end{array}$ & 0 \\
\hline 2 & $\begin{array}{l}\text { Acacia-poplar plantation } \\
\text { with small balsam }\end{array}$ & xeromesophilous & $\begin{array}{c}55 \text { (Populus italica (Du Roi) } \\
\text { Moench }-45, \text { Robinia } \\
\text { pseudoacacia } \text { L. }-10)\end{array}$ & $\begin{array}{l}5 \text { (Swida sanguinea } \\
\quad \text { (L.) Opiz. }-5)\end{array}$ & $\begin{array}{c}80 \text { (Impatiens parviflora } \text { L. }-80, \\
\text { Chelidonium majus } \text { L. }-3 \text { ) }\end{array}$ \\
\hline 3 & $\begin{array}{l}\text { Poplar plantation } \\
\text { with various } \\
\text { ruderal plants }\end{array}$ & mesohygrophilous & $\begin{array}{c}75 \text { (Populus italica (Du Roi) } \\
\text { Moench }-75)\end{array}$ & 0 & $\begin{array}{c}30 \text { (Elytrigia repens L. }-10, \\
\text { Ambrosia artemisiifolia } \text { L. }-8 \text {, } \\
\text { Ballota nigra } \text { L. }-5, \text { Geum } \\
\text { urbanum } \text { L. }-5, \text { Solidago } \\
\text { virgaurea } \text { L. }-3 \text { ) }\end{array}$ \\
\hline 4 & $\begin{array}{l}\text { Poplar plantation } \\
\text { with bare soil }\end{array}$ & mesoxerophilous & 65 (Populus deltoides Marsh. - 65) & $\begin{array}{c}65 \text { (Sambucus nigra L. }-45, \\
\text { Morus nigra L. }-20)\end{array}$ & ( \\
\hline 5 & $\begin{array}{l}\text { Sycamore-poplar } \\
\text { plantation with bare soil }\end{array}$ & mesophilous & $\begin{array}{c}90 \text { (Populus italica (Du Roi) } \\
\text { Moench - 75, Acer negundo L. - } \\
\text { 10, Acer tataricum L. - - })\end{array}$ & 0 & 0 \\
\hline 6 & $\begin{array}{l}\text { Poplar-willow plantation } \\
\text { with common hop }\end{array}$ & mesohygrophilous & $\begin{array}{c}70 \text { (Populus alba } \text { L. }-65 \\
\text { Salix alba } \text { L. }-8)\end{array}$ & $\begin{array}{c}90(\text { Humulus } \\
\text { lupulus L. }-90)\end{array}$ & 5 (Equisetum arvense L. -5 ) \\
\hline 7 & $\begin{array}{l}\text { White poplar with } \\
\text { Virginia creeper and } \\
\text { common hop }\end{array}$ & hygromesophilous & 95 (Populus alba L. - 95) & $\begin{array}{l}35 \text { (Parthenocissus quinquefolia } \\
\text { Planch. - 15, Humulus lupulus L.-- } \\
\text { 15, Swida sanguinea (L.) Opiz. -5) }\end{array}$ & $\begin{array}{l}7 \text { (Geum urbanum L. }-5 \text {, } \\
\text { Torilis japonica }(\text { Houtt. })-2)\end{array}$ \\
\hline 8 & $\begin{array}{l}\text { Elm-poplar plantation } \\
\text { with desert false indigo, } \\
\text { bare soil }\end{array}$ & mesophilous & $\begin{array}{l}95 \text { (Populus italica (Du Roi) } \\
\text { Moench - 85, Ulmus carpinifolia } \\
\text { Rupp. ex G. Suckow - 10) }\end{array}$ & 2 (Amorpha fruticosa $\mathrm{L} .-2$ ) & 0 \\
\hline
\end{tabular}

\section{Results}

The total number of litter macrofauna in the poplar plantations varied within a wide range. The dominance of one or two species of invertebrates in particular forest plots can account for extremely high numbers of invertebrates $\left(187 \mathrm{specimen} / \mathrm{m}^{2}\right)$, more than three times the average value for the studied plantation types $\left(53 \mathrm{specimen} / \mathrm{m}^{2}\right)$ (Fig. $1 a)$. The study plots varied $\left(\mathrm{F}=12.47, \mathrm{P}=4.3 * 10^{-7}\right)$ widely in the number of species they supported. The greatest variety of species was collected from the plantations of white poplar with common hop and elm and poplar plantations with Amorpha fruticosa $\mathrm{L}$. and bare soil (15 and 9 species correspondingly) (Fig. 1b). The ShannonWeaver diversity index includes the number of species on a study plot, hence its value reaches its maximum for the abovementioned plots (3.2 and 2.9 bits respectively). The Pielou index shows the range of species uniformity according to their number, assesses the absence of dominant species in communities and reaches a high level $(0.55$ 0.99 bits) (Fig. $1 c, d$ ) in all the studied forest types.

The trophic structure of the litter macrofauna of poplar plantations is distinguished by the irregular distribution of the main functional groups. The percentage of phytophages in the total number of invertebrates in the study plots varied significantly $(0-70 \%)$. The greatest share of phytophages in the litter macrofauna was seen in forest ecosystems with a well developed shrub and herbaceous layer, on plots of mesohygrophilous moisture type. A rapid decrease in the number of phytophages was registered on the plots with a thinned-out herbaceous layer (or where herbaceous plants were absent) and in types of plantations with xeromesophilous moisture conditions (0-13\%) (Fig. $2 a$ ).

Variation in numbers of zoophages in different poplar plantations was not manifested (Fig. 2c). The dominant families (a family was considered to be dominant if it comprised $5 \%$ or more of the total number of litter invertebrates at a site) were Lycosidae, Carabidae, Staphylinidae. The greatest number $(40 \%)$ of total predator inverte- brates was registered in the white poplar plantation with common hop. The distribution of Staphylinidae individuals across the study plots was irregular. In the studied types of artificial forests a decrease in species variety within this family was observed and a relatively low number of individuals $\left(1-6 \mathrm{specimen} / \mathrm{m}^{2}\right)$. The greatest number of Staphylinidae species was registered in the litter horizon of forest plots with a developed shrub layer, characterized by mesophilous, mesohygrophilous and hygromesophilous moisture conditions, which is partly caused by the hygrophilous character of these insects and their need for shade. The dominants in the litter of the poplar plantations were Xantholinus linearis (Olivier, 1795), Falagria sulcatula (Gravenhorst, 1806), Rugilus similis Erichson, 1840, Cryptobium fracticorne (Paykull, 1800), Drusilla canaliculata (Fabricius, 1787), Medon apicalis (Kraatz, 1857). In the drier poplar plantations Staphylinus caesareus Cederhjelm, 1798, Tachyporus hypnorum (Fabricius, 1775), Astenus immaculatus Stephens, 1832 were registered (Table 2).

The number of ground beetles was higher in mesophilous poplar plantations (0.5-7.0 specimen $/ \mathrm{m}^{2}$ ). Asaphidion flavipes (Linnaeus, 1761), Bembidion lampros (Herbst, 1784), Harpalus rufipes (De Geer, 1774) and Microlestes minutulus (Goeze, 1777) were recorded in almost all the studied poplar plantations. In drier plantations these species were supplemented by steppe, mesophilous forest and ubiquitist, species: Notiophilus laticollis Chaudoir, 1850, Poecilus versicolor (Sturm, 1824), Pterostichus ovoideus (Sturm, 1824), Calathus fuscipes (Goeze, 1777), Amara similata (Gyllenhal, 1810), Harpalus tardus (Panzer, 1797), H. ampicollis Menetries, 1848, Licinus depressus (Paykull, 1790), Badister bullatus (Schrank, 1798) and Syntomus truncatellus (Linnaeus, 1761). In the moist conditions of white poplar plantations, hygrophilous species of Carabidae were present: Clivina fossor (Linnaeus, 1758), Pterostichus anthracinus (Illiger, 1798), Agonum lugens (Duftschmid, 1812), Oxypselaphus obscurum (Herbst, 1784), Stenolophus teutonus (Schrank, 1781) and S. proximus Dejean, 1829. All these species of ground beetle are characteristic of the region under research. Specialized and rare species of ground beetle were not found in the forest plantations studied. 

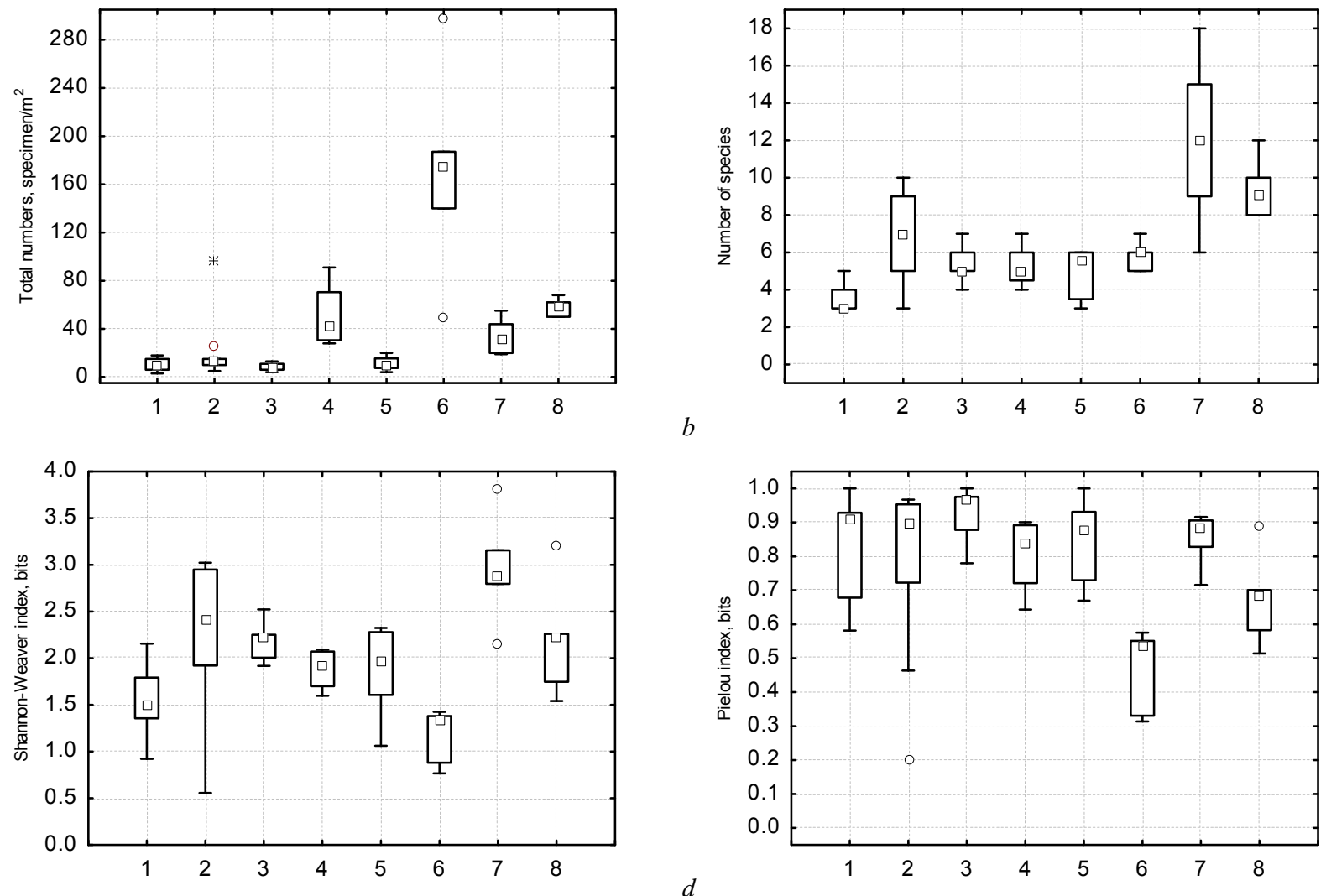

Fig. 1. Basic characteristics of litter macrofauna of poplar plantations: $a$-total numbers (specimen $/ \mathrm{m}^{2}$ ), $b$ - number of species, $c$-Shannon-Weaver index (bits), $d$ - Pielou index (bits); abscissia - sample plot (see Table 1), ordinate - value of the characteristic; on this and Fig. 2-5 the small squares shown the median, the large rectangles show the $25 \%$ and $75 \%$ quartiles, the vertical lines show $95 \%$ of the variation, the stars and circles show the outliers
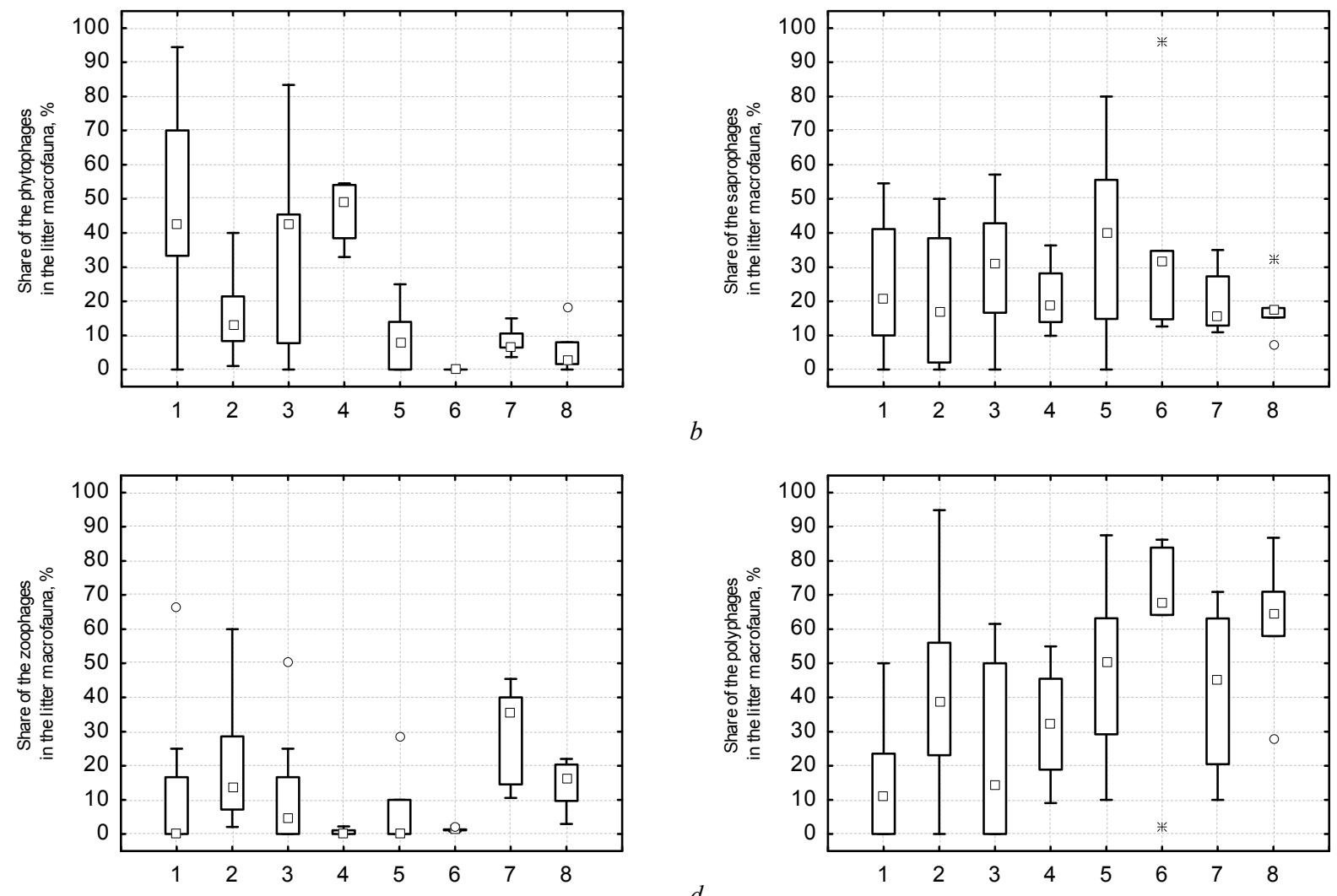

Fig. 2. Trophic structure (by abundance) of the litter macrofauna of poplar plantations: $a$ - phytophages, $b$ - saprophages, $c$-zoophages, $d$-polyphages; abscissia - sample plot (see Table 1), ordinate - share of the trophic group in the litter macrofauna (\%) 
Table 2

Taxonomic composition of the species found on the study plots in relation to distribution across the 64 subplots, trophic and size groups

\begin{tabular}{|c|c|c|c|c|c|}
\hline Order & Family & Species & $\begin{array}{c}\text { Frequency, } \\
\text { \% subplots where } \\
\text { species was found }\end{array}$ & $\begin{array}{l}\text { Size group, } \\
\text { average body } \\
\text { length in mm }\end{array}$ & $\begin{array}{l}\text { Trophic group, according } \\
\text { to commonest category } \\
\text { of food consumed }\end{array}$ \\
\hline 1 & 2 & 3 & 4 & 5 & 6 \\
\hline Lumbricomorpha & Lumbricidae & Dendrobaena sp. & 1.6 & $>20$ & $\mathrm{~s}$ \\
\hline Lumbricomorpha & Lumbricidae & Octolasion sp. & 4.7 & $>20$ & $\mathrm{~s}$ \\
\hline Isopoda & Armadillidiidae & Armadillidium vulgare (Latreille, 1804) & 1.6 & $4-7$ & $\mathrm{~s}$ \\
\hline Isopoda & Porcellionidae & Porcellio laevis Latreille, 1804 & 14.1 & $4-7$ & $\mathrm{~s}$ \\
\hline Isopoda & Porcellionidae & P. scaber Latreille, 1804 & 57.8 & $4-7$ & $\mathrm{~s}$ \\
\hline Diplopoda & Polydesmidae & Turanodesmus dmitriewi (Timopheev, 1897) & 3.1 & $16-19$ & $\mathrm{~s}$ \\
\hline Geophilomorpha & Geophilidae & Arctogeophilus sp. & 6.3 & $16-19$ & $\mathrm{z}$ \\
\hline Lithobiomorpha & Lithobiidae & Lithobius forficatus (Linnaeus, 1758) & 9.4 & $12-15$ & $\mathrm{z}$ \\
\hline Collembola & Entomobriidae & Entomobrya sp. & 12.5 & $<4$ & $\mathrm{~s}$ \\
\hline Hemiptera & Lygaeidae & Trapezonotus sp. & 9.4 & $4-7$ & $\mathrm{z}$ \\
\hline Hemiptera & Lygaeidae & Scolopostethus sp. & 18.8 & $4-7$ & $\mathrm{z}$ \\
\hline Hemiptera & Miridae & Miridae sp. & 1.6 & $4-7$ & $\mathrm{p}$ \\
\hline Hemiptera & Nabidae & Nabidae sp. 1 & 6.3 & $4-7$ & $\mathrm{p}$ \\
\hline Hemiptera & Nabidae & Nabidae sp. 2 & 1.6 & $4-7$ & $\mathrm{p}$ \\
\hline Hemiptera & Nabidae & Nabis ferus (Linnaeus 1758) & 3.1 & $4-7$ & $\mathrm{p}$ \\
\hline Hemiptera & Pirrhocoridae & Pyrrhocoris apterus (Linnaeus, 1758) & 20.3 & $8-11$ & $\mathrm{p}$ \\
\hline Hemiptera & Lygaeidae & Lygaeidae sp. 1 & 6.3 & $8-11$ & $\mathrm{z}$ \\
\hline Hemiptera & Lygaeidae & Lygaeidae sp. 2 & 1.6 & $4-7$ & $\mathrm{z}$ \\
\hline Hymenoptera & Formicidae & Dolichoderus quadripunctatus (Linnaeus, 1771) & 6.3 & $4-7$ & $\mathrm{p}$ \\
\hline Hymenoptera & Formicidae & Formica cinerea Mayr, 1853 & 12.5 & $4-7$ & $\mathrm{p}$ \\
\hline Hymenoptera & Formicidae & F. glauca Ruzsky, 1896 & 18.8 & $4-7$ & $\mathrm{p}$ \\
\hline Hymenoptera & Formicidae & F. pratensis Retzius, 1783 & 6.3 & $4-7$ & $\mathrm{p}$ \\
\hline Hymenoptera & Formicidae & Lasius alienus (Foerster, 1850) & 1.6 & $<4$ & $\mathrm{p}$ \\
\hline Hymenoptera & Formicidae & L. flavus (Fabricius, 1782) & 3.1 & $<4$ & $\mathrm{p}$ \\
\hline Hymenoptera & Formicidae & L. niger (Linnaeus, 1758) & 1.6 & $<4$ & $\mathrm{p}$ \\
\hline Hymenoptera & Formicidae & L. platythorax Seifert, 1991 & 59.4 & $<4$ & $\mathrm{p}$ \\
\hline Hymenoptera & Formicidae & Myrmica ruginodis Nylander, 1846 & 6.3 & $4-7$ & $\mathrm{p}$ \\
\hline Hymenoptera & Formicidae & M. scabrinodis Nylander, 1846 & 28.1 & $4-7$ & $\mathrm{p}$ \\
\hline Hymenoptera & Formicidae & Ponera coarctata (Latreille, 1802) & 1.6 & $<4$ & $\mathrm{p}$ \\
\hline Hymenoptera & Formicidae & Tetramorium caespitum (Linnaeus, 1758) & 3.1 & $<4$ & $\mathrm{p}$ \\
\hline Neuroptera & Chrysopidae & Chrysoperla carnea (Stephens, 1836) & 1.6 & $8-11$ & $\mathrm{z}$ \\
\hline Neuroptera & Hemerobiidae & Hemerobiidae sp. & 1.6 & $4-7$ & $\mathrm{z}$ \\
\hline Diptera & Stratiomyidae & Stratiomyidae sp., larvae & 1.6 & $4-7$ & $\mathrm{~s}$ \\
\hline Diptera & Sarcophagidae & Sarcophagidae sp. & 1.6 & $12-15$ & $\mathrm{~s}$ \\
\hline Diptera & Tipulidae & Tipulidae sp. & 3.1 & $12-15$ & $\mathrm{~s}$ \\
\hline Coleoptera & Carabidae & Asaphidion flavipes (Linnaeus, 1761) & 1.6 & $<4$ & $\mathrm{z}$ \\
\hline Coleoptera & Carabidae & Badister bullatus (Schrank, 1798) & 1.6 & $4-7$ & $\mathrm{z}$ \\
\hline Coleoptera & Carabidae & Bembidion lampros (Herbst, 1784) & 4.7 & $<4$ & $\mathrm{z}$ \\
\hline Coleoptera & Carabidae & Curtonotus aulicus (Panzer, 1796) & 3.1 & $12-15$ & $\mathrm{ph}$ \\
\hline Coleoptera & Carabidae & Harpalus rufipes (De Geer, 1774) & 3.1 & $12-15$ & $\mathrm{p}$ \\
\hline Coleoptera & Carabidae & Microlestes minutulus (Goeze, 1777) & 10.9 & $<4$ & $\mathrm{z}$ \\
\hline Coleoptera & Carabidae & Syntomus truncatellus (Linnaeus, 1761) & 6.3 & $<4$ & $\mathrm{z}$ \\
\hline Coleoptera & Staphylinidae & Astenus immaculatus Stephens, 1832 & 3.1 & $<4$ & $\mathrm{z}$ \\
\hline Coleoptera & Staphylinidae & Atheta $s p$ & 3.1 & $<4$ & $\mathrm{z}$ \\
\hline Coleoptera & Staphylinidae & Cryptobium fracticorne (Paykull, 1800) & 1.6 & $4-7$ & $\mathrm{z}$ \\
\hline Coleoptera & Staphylinidae & Drusilla canaliculata (Fabricius, 1787) & 1.6 & $4-7$ & $\mathrm{z}$ \\
\hline Coleoptera & Staphylinidae & Falagria sulcatula (Gravenhorst, 1806) & 1.6 & $<4$ & $\mathrm{z}$ \\
\hline Coleoptera & Staphylinidae & Lathrobium $s p$. & 1.6 & $8-11$ & $\mathrm{z}$ \\
\hline Coleoptera & Staphylinidae & Medon apicalis (Kraatz, 1857) & 1.6 & $<4$ & $\mathrm{z}$ \\
\hline Coleoptera & Staphylinidae & Rugilus similis Erichson, 1840 & 1.6 & $4-7$ & $\mathrm{z}$ \\
\hline Coleoptera & Staphylinidae & Staphylinus caesareus Cederhjelm, 1798 & 4.7 & $16-19$ & $\mathrm{z}$ \\
\hline Coleoptera & Staphylinidae & Xantholinus linearis (Olivier, 1795) & 4.7 & $8-11$ & $\mathrm{z}$ \\
\hline Coleoptera & Staphylinidae & Tachyporus hypnorum (Fabricius, 1775) & 10.9 & $4-7$ & $\mathrm{z}$ \\
\hline Coleoptera & Coccinellidae & Coccinella septempunctata Linnaeus, 1758 & 3.1 & $<4$ & $\mathrm{z}$ \\
\hline Coleoptera & Coccinellidae & Propylea quatuordecimpunctata (Linnaeus, 1758) & 1.6 & $4-7$ & $\mathrm{z}$ \\
\hline Coleoptera & Curculionidae & Curculionidae sp. & 1.6 & $4-7$ & $\mathrm{ph}$ \\
\hline Coleoptera & Curculionidae & Otiorhynchus raucus (Fabricius, 1777) & 1.6 & $4-7$ & $\mathrm{ph}$ \\
\hline Coleoptera & Cantharidae & Cantharidae sp., larvae & 3.1 & $4-7$ & $\mathrm{z}$ \\
\hline Coleoptera & Cerambycidae & Cerambycidae sp., larvae & 1.6 & $8-11$ & $\mathrm{ph}$ \\
\hline Lepidoptera & Noctuidae & Noctuidae sp. 1 & 1.6 & $>20$ & $\mathrm{ph}$ \\
\hline Raphidioptera & Raphidiidae & Dichrostigma flavipes (Stein, 1863), larvae & 6.3 & $8-11$ & $\mathrm{z}$ \\
\hline Dermaptera & Forficulidae & Forficula auricularia Linnaeus, 1758 & 3.1 & $16-19$ & $\mathrm{p}$ \\
\hline Araneae & Araneidae & Cercidia prominens (Westring, 1851) & 1.6 & $4-7$ & $\mathrm{z}$ \\
\hline Araneae & Clubionidae & Clubionidae sp., juv. & 4.7 & $<4$ & $\mathrm{z}$ \\
\hline Araneae & Dictynidae & Robertus arundineti (O. Pickard-Cambridge, 1871) & 1.6 & $<4$ & $\mathrm{z}$ \\
\hline Araneae & Dysderidae & Dysderidae sp., juv. & 1.6 & $<4$ & $\mathrm{z}$ \\
\hline Araneae & Gnaphosidae & Gnaphosidae sp., juv. & 3.1 & $<4$ & $\mathrm{z}$ \\
\hline Araneae & Linyphiidae & Maso sundevalli (Westring, 1851) & 1.6 & $<4$ & $\mathrm{z}$ \\
\hline Araneae & Linyphiidae & Neriene clathrata (Sundevall, 1830) & 1.6 & $<4$ & $\mathrm{z}$ \\
\hline Araneae & Linyphiidae & Tenuiphantes flavipes (Blackwall, 1854) & 1.6 & $<4$ & $\mathrm{z}$ \\
\hline Araneae & Linyphiidae & Linyphiidae sp., juv. & 1.6 & $<4$ & $\mathrm{z}$ \\
\hline
\end{tabular}




\begin{tabular}{|c|c|c|c|c|c|}
\hline 1 & 2 & 3 & 4 & 5 & 6 \\
\hline Araneae & Lycosidae & Lycosidae sp., juv. & 4.7 & $<4$ & $\mathrm{z}$ \\
\hline Araneae & Philodromidae & Thanatus sp., juv. & 1.6 & $<4$ & $\mathrm{z}$ \\
\hline Araneae & Tetragnathinae & Tetragnatha sp., juv. & 3.1 & $<4$ & $\mathrm{z}$ \\
\hline Araneae & Theridiidae & Parasteatoda tepidariorum (C. L. Koch, 1841) & 1.6 & $4-7$ & $\mathrm{z}$ \\
\hline Araneae & Theridiidae & Theridiidae sp., juv. & 1.6 & $<4$ & z \\
\hline Araneae & Thomisidae & Thomisidae sp., juv & 3.1 & $<4$ & $\mathrm{z}$ \\
\hline Araneae & Titanoecidae & Titanoecidae sp., juv. & 1.6 & $<4$ & $\mathrm{z}$ \\
\hline Pulmonata & Arionidae & Arion subfuscus (Draparnaud, 1805) & 12.5 & $>20$ & $\mathrm{ph}$ \\
\hline Pulmonata & Cochlicopidae & Cochlicopa lubrica (O. F. Muller, 1774) & 20.3 & $4-7$ & $\mathrm{ph}$ \\
\hline Pulmonata & Cochlicopidae & C. lubricella (Rossmassler, 1834) & 12.5 & $4-7$ & $\mathrm{ph}$ \\
\hline Pulmonata & Gastrodontidae & Zonitoides nitidus (O. F. Muller, 1774) & 25.0 & $4-7$ & $\mathrm{ph}$ \\
\hline Pulmonata & Oxychilidae & Aegopinella minor (Stabile, 1864) & 4.7 & $4-7$ & $\mathrm{ph}$ \\
\hline Pulmonata & Succineidae & Succinea putris (Linnaeus, 1758) & 1.6 & $16-19$ & $\mathrm{ph}$ \\
\hline Pulmonata & Succineidae & Succinella oblonga (Draparnaud, 1801) & 18.8 & $4-7$ & $\mathrm{ph}$ \\
\hline
\end{tabular}

Notes: trophic groups of the litter macrofauna: $\mathrm{ph}$ - phytophages, $\mathrm{z}$ - zoophages, $\mathrm{p}$ - polyphages, $\mathrm{s}$ - saprophages.

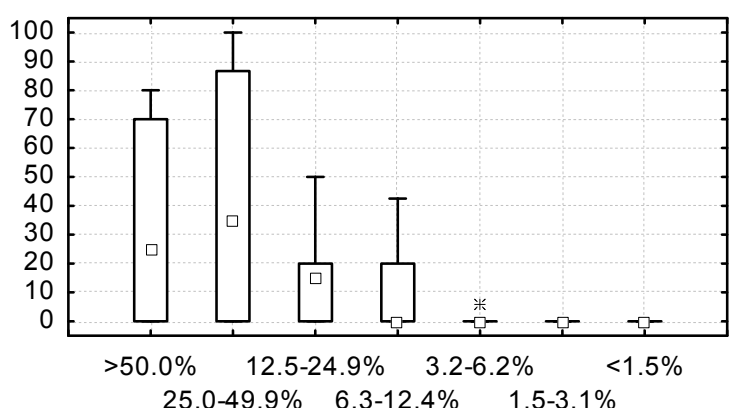

a

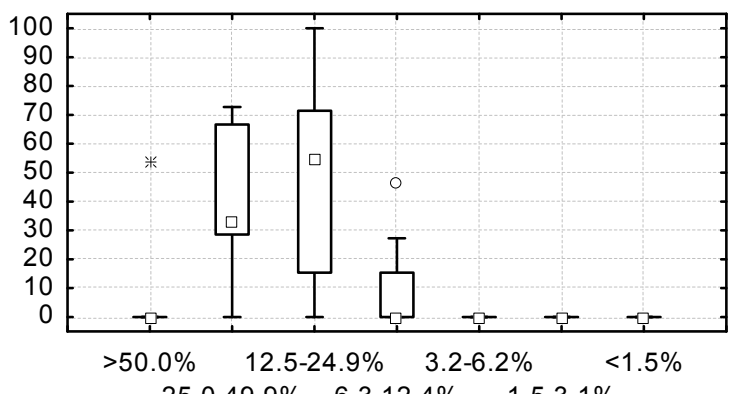

c
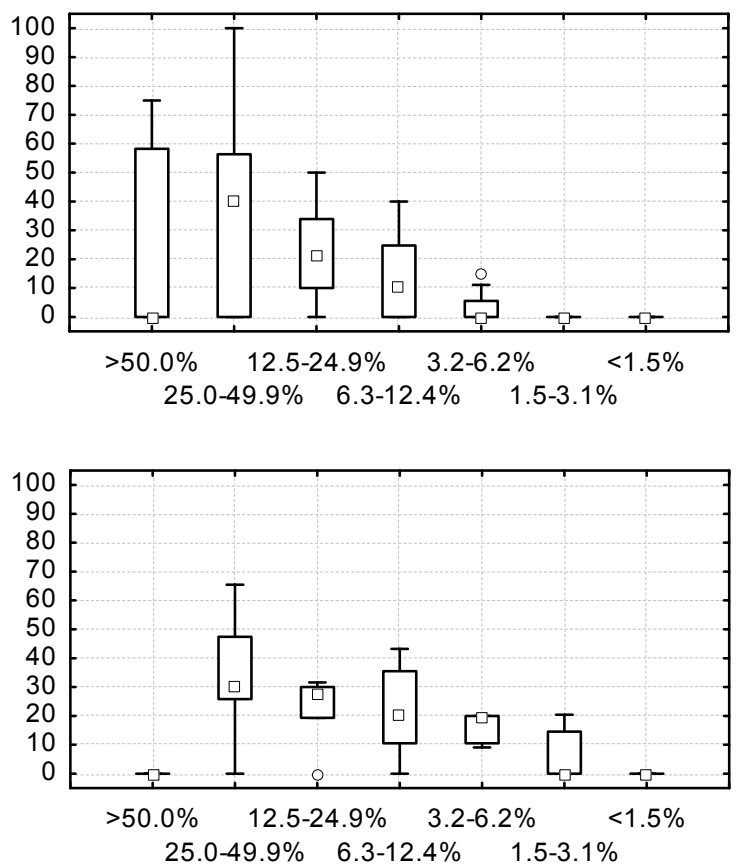

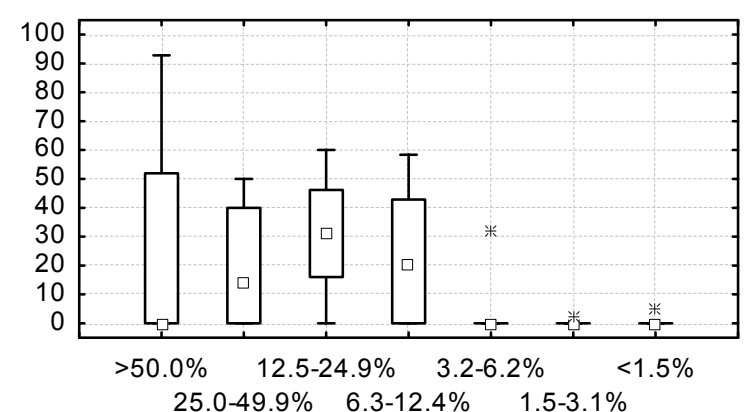

b

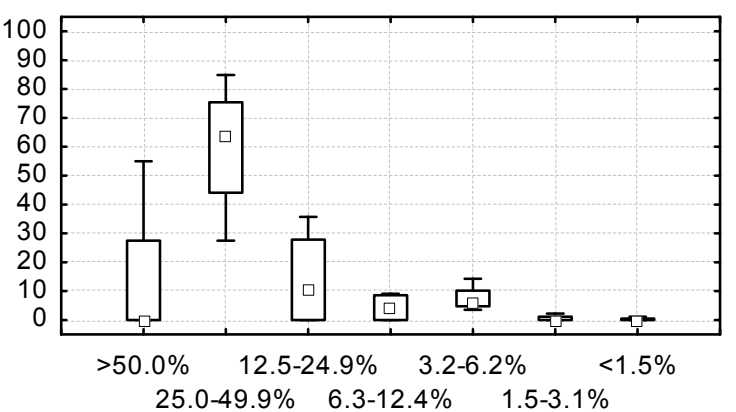

$d$

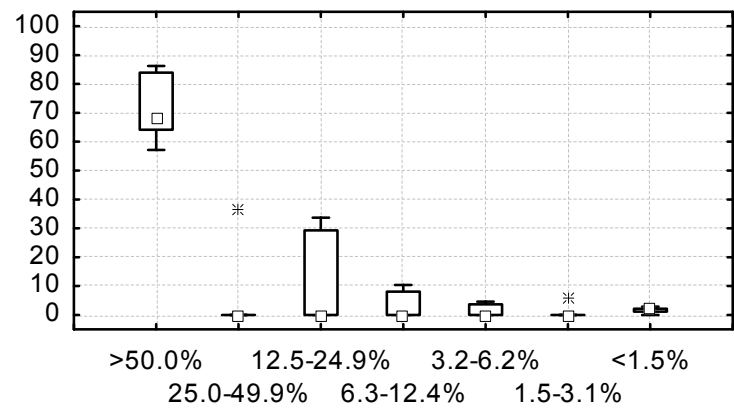

f

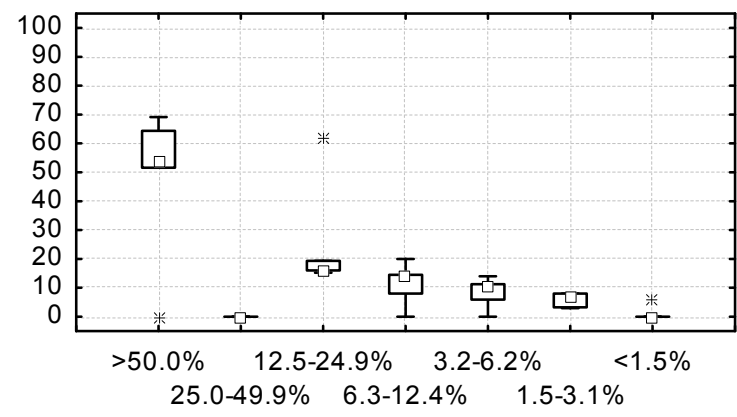

Fig. 3. Dominance structure of the litter macrofauna of poplar plantations: $a-h$-sample plot 1-8 (see Table 1); abscissa - share of the species in the community (\%), ordinate - numerical dominance of given group of species (\%) 
The distribution of Araneae by habitat was also observed to have an irregular character. In xeromesophilous and mesophilous poplar plantations litter spiders were uncommon $\left(0-1 \mathrm{specimen} / \mathrm{m}^{2}\right)$, the main species being Parasteatoda tepidariorum (C. L. Koch, 1841) and Tenuiphantes flavipes (Blackwell, 1854). Possibly this is connected to the limited food base provided by plantations in xeromesophilous and mesophilous moisture conditions, the sparseness of the vegetation and the highly irregular moisture regime (Polchaninova and Prokopenko, 2013). The species diversity of spiders was greatest in hygomesophilous and mesophilous plantations of Populus alba L. The most numerous were juveniles of the following groups: Lycosidae, Gnaphosidae (5-7 specimens $\left./ \mathrm{m}^{2}\right)$, Dysderidae, Linyphiidae, Clubionidae and Thomisidae $\left(1-2\right.$ specimen $\left./ \mathrm{m}^{2}\right)$.

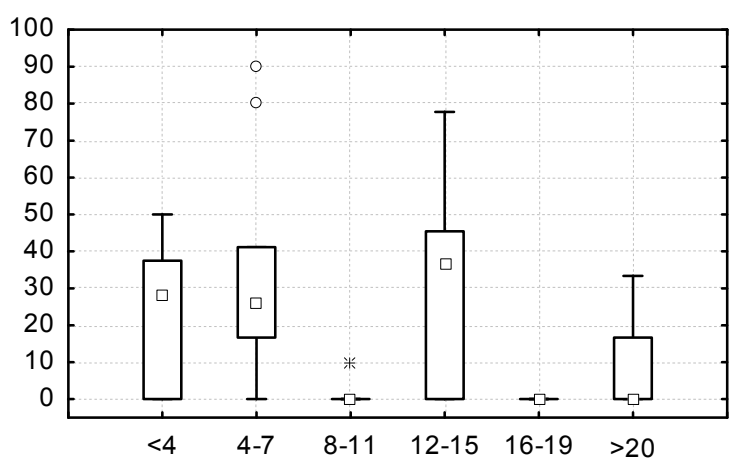

$a$

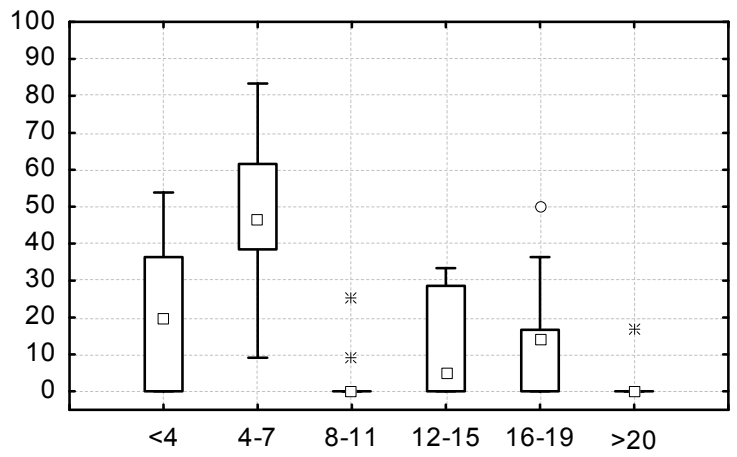

$c$

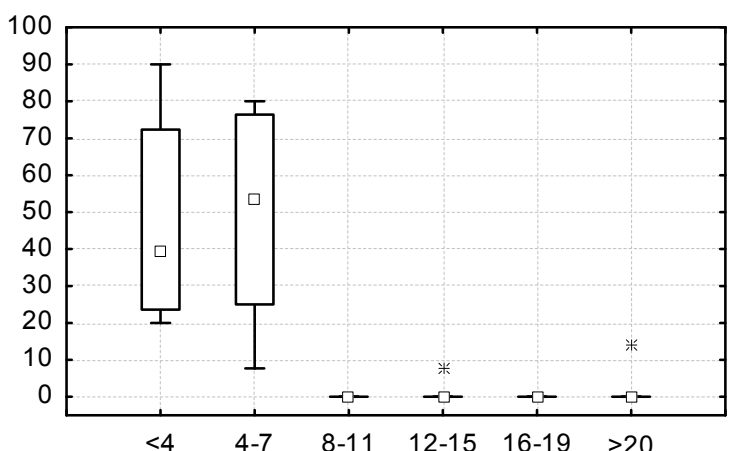

$e$

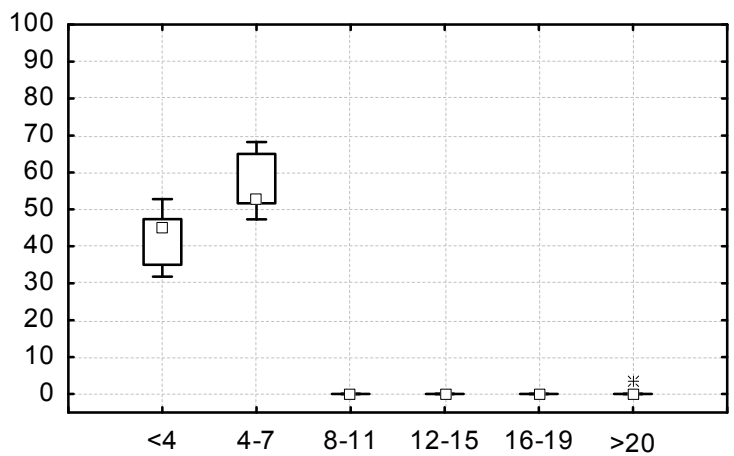

Fig. 4. Size strucure of litter macrofauna in poplar plantations: $a-h$-sample plot 1-8 (see Table 1); abscissa - individuals' body length (mm), ordinate - share of individuals with given size group in the community (\%)
In the litter horizon of forest plantations of the steppe zone saprophages and polyphages form the numerically dominant groups. The abundance of saprophages (Fig. 2) fluctuated insignificantly (from $19-66 \% ; \mathrm{F}=1.19, \mathrm{P}=0.21$ ) depending on the type of poplar plantation. The median number of saprophages reached its maximum in moist (mesophilous and mesohygophilous) plots with a thick litter layer. The most numerous representatives were Isopoda (Porcellio scaber Latreille, 1804 - 5-18 specimen $/ \mathrm{m}^{2}$ ), Pulmonata (Succinea putris (Linnaeus, 1758), Succinella oblonga (Draparnaud, 1801), Cochlicopa lubrica (O. F. Muller, 1774), C. lubricella (Rossmassler, 1834), Aegopinella minor (Stabile, 1864) and Zonitoides nitidus (O. F. Muller, 1774)).

b
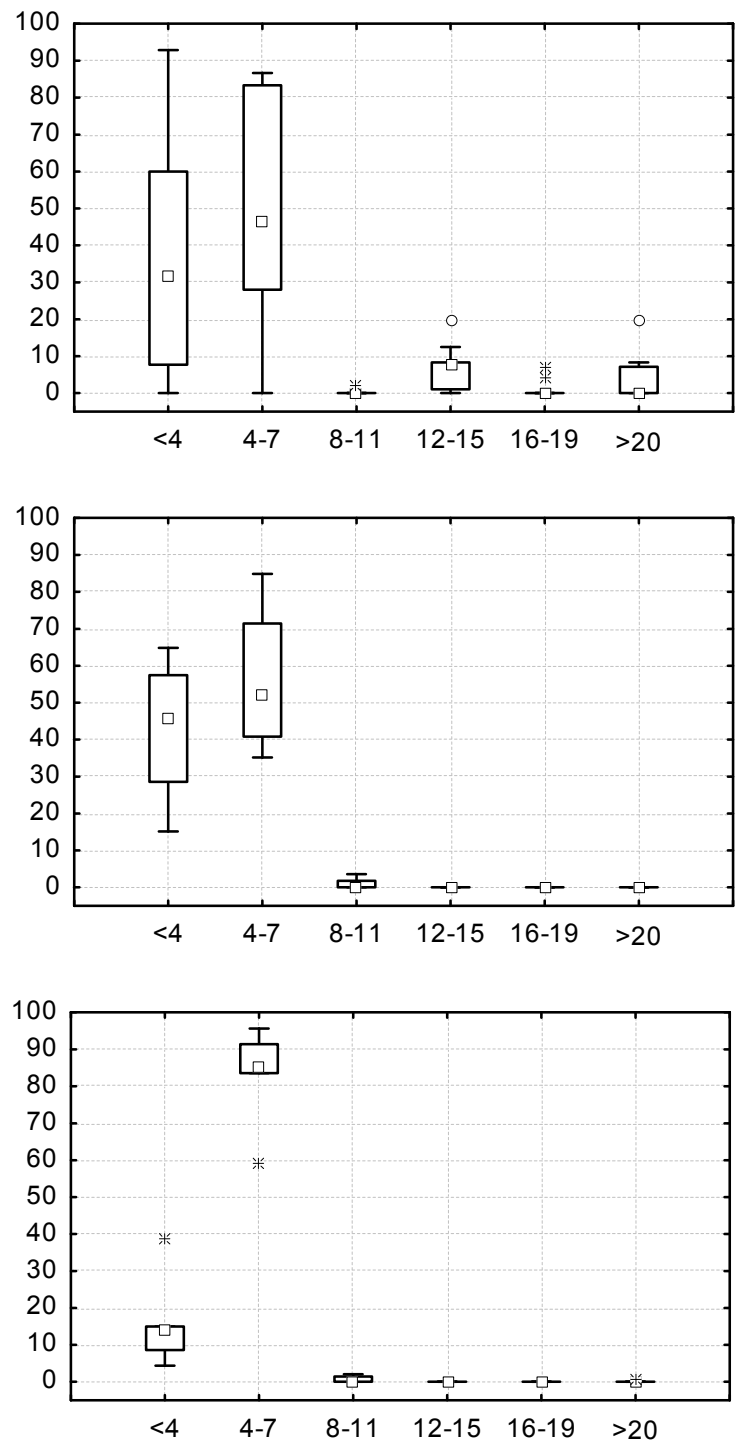

$f$

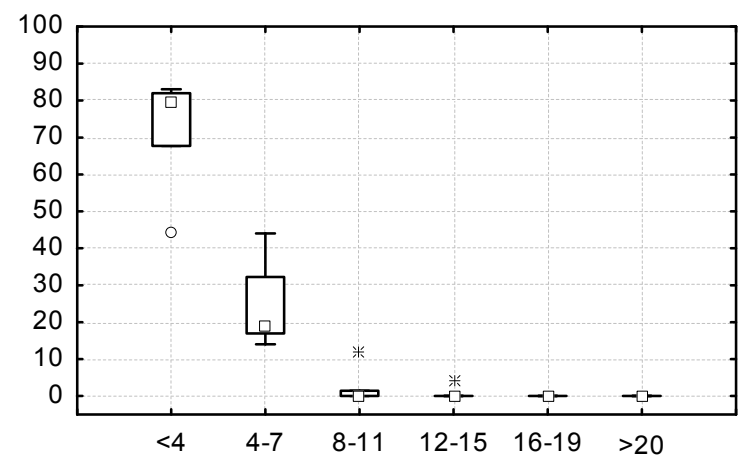


The polyphage group was represented mainly by ant species: Formica glauca Ruzsky, 1896, F. cinerea Mayr, 1853, F. pratensis Retzius, 1783, Lasius niger (Linnaeus, 1758), L. platythorax Seifert, 1991, L. alienus (Forster, 1850), L. flavus (Fabricius, 1782), and more rarely by Myrmica scabrinodis Nylander, 1846, M. ruginodis Nylander, 1846, Tetramorium caespitum (Linnaeus, 1758) and Dolichoderus quadripunctatus (Linnaeus, 1771). Overall, polyphages were numerous on all the study plots, their abundance varying from $24 \%$ to $85 \%$ of the total numbers of invertebrates. Their maximum numbers were noted in floodplain plantations of Populus alba L. in hygromesophilous and mesophilous conditions.

The dominance structure (Fig. 3) characterizes the resistance of ecosystems to external influences. The presence of a group of species which composed over $50 \%$ of the total number of the litter macrofauna in 7 of the 8 studied poplar plantations (with the exception of the white poplar plantation with Virginia creeper (Parthenenocissus quinquefolia (L.) Planch.) and common hop (Humulus lupulus L.) (Fig. 3g) indicates the unbalanced taxonomic structure of the communities. Species of average relative abundance (6.3-24.9\%) provide a varied stream of energy to an ecosystem, they can promote a change in the functional regime of litter macrofauna, and, under certain conditions, can become dominant. In half the researched poplar plantations species of average abundance (for a given ecosystem) accounted for about half the species collected (Fig. $3 b, c, e, g$ ), while in the remaining ecosystems the percentage was very low. The share of species which are rare for a particular ecosystem (with a relative abundance of less than $6.2 \%$ ), with the exception of two moister ecosystems (Fig. $3 g, h$ ) did not exceed $10 \%$, which indicates a lack of potential resources for renewal of the dominance structure of species in case of change in the conditions of an urban ecosystem.

The size structure of an invertebrate community reflects the completeness of use by the litter fauna of the trophic resources of an ecosystem. A community which contains all size groups can be considered to be more saturated with species and life forms, its ecological niches are more varied (narrow, specialized and diversified), and so such an ecosystem can be considered more stable in relation to external influences. The urban poplar plantations investigated are distinguished by the simplified size structure of the litter macrofauna (Fig. 4). The dominant groups in most of the study plots were invertebrates 4-7 mm long (the position of the peak in the diagrams fluctuates between $44 \%$ and $96 \%$ ). An analogical percentage of domination for this size group has been observed for other types of forest plantation in the steppe zone. The abundance (expressed as a percentage) of the smallest size group of litter invertebrates, under $4 \mathrm{~mm}$, reaches 93\% on some plots (acacia-poplar plantations with small balsam (Impatiens parviflora DC.)). The high abundance of this size group is an indicator of a relatively stable temperature and moisture regime over the course of a season.

In the types of poplar plantations researched a significant violation of the norms for the size structure of the macrofauna was observed, with reduction in the number of size groups. In the poplar-willow bed with common hops (Fig. 4f) the share of the size group of less than $4 \mathrm{~mm}$ was only $16 \%$, while species belonging to the size groups of $8-11,12-15,16-19$ and over $20 \mathrm{~mm}$ in body length were entirely absent. The size group $4-7 \mathrm{~mm}$ dominated (96\%) on account of the high numbers of the ant species Myrmica scabrinodis Nylander, 1846 and Lasius platythorax Seifert, 1991. An analogical percentage ratio of size groups was observed for the majority of the forest plots researched. The absence of species with body length exceeding $8 \mathrm{~mm}$ (Fig. $4 d, e, g, h$ ) indicates an unstable ecosystem and damage to the most important trophic chain. For different types of poplar plantation (Fig. 4a) the size structure of the litter macrofauna shows a double peak (invertebrates of two size groups dominate with considerably lesser numbers for the size groups inbetween). Additional peaks in the size structure could be seen as indicators of disturbance to an ecosystem.

Analysis of the taxonomic structure of the litter macrofauna (Fig. 5) shows that Formicidae dominate in all types of poplar planta- tion. The most clear case of dominant status of ants ( 150 speci$\mathrm{men} / \mathrm{m}^{2}$ ) was observed in plots with mesohygrophilous and mesophilous moisture regimes, under which conditions the numbers of other types of invertebrates did not exceed 35 specimen $/ \mathrm{m}^{2}$ (Fig. $5 f, h$ ). The second most dominant group, numerous on almost all study plots was Geophilia. The moisture conditions in the studied poplar plantations, the light regime and the food resources were optimal for land molluscs. In some types of plantation (Fig. $5 b, e, f$ ) Porcellionidae shared an equal place with molluscs in the dominance structure, which is characteristic of artificial forests of the steppe zone. In the studied poplar plantations, which grow in steppe ecosystems with insignificant moisture of the soil and litter horizons (an ecosystem which takes up half the territory of Ukraine), higher numbers of Lygaeidae were observed (up to 7 specimen $/ \mathrm{m}^{2}$ ) (Fig. $5 d$ ). Saprophages (Julidae, Silphidae) and zoophages (Araneae, Carabidae, Staphylinidae), which are numerous in both natural and plantation forests of the steppe zone, were either entirely absent from the taxonomic structure or were present in low numbers $\left(1-6\right.$ specimen $\left./ \mathrm{m}^{2}\right)$ in the studied poplar plantations.

\section{Discussion}

The total number of litter macrofauna for poplar plantations does not significantly differ from similar indicators in natural bottomland forests and ravine broadleaved forests of Ukraine's steppe zone (Brygadyrenko, 2014, 2015c). The variations in the data for the different study plots means that this group cannot be used to conduct a univocal system of habitat indicators for poplar plantations (Ferguson and Berube, 2004; Pearce and Venier, 2006; Malaque et al., 2008; Schuldt et al., 2008).

The abundance of any particular macrofauna group is determined primarily by the trophic connections within a litter horizon community. The trophic connections with the food resources of the soil layer, herbaceous layer, tree and shrub layers increases in those plots where the depth of the litter does not exceed 10-20 mm, and therefore cannot maintain optimal conditions for the macrofauna during the period of summer drought. The number of mesophilous invertebrate species (the inhabitants of litter, as opposed to the inhabitants of soil and plant stand which occasionally appear on the soil surface) is significantly lower in poplar plantations without a developed litter layer. In mesohygrophilous poplar plantations a thicker litter layer $(30-40 \mathrm{~mm})$ supports a constant moisture regime and hence a richer and more stable macrofauna.

One of the mechanisms of stability in natural ecosystems is the distribution of the various species which inhabit it into ecological niches, which often overlap. The richness of an ecological niche within an ecosystem depends, first of all, upon the microclimatic conditions that develop within the biotope. The more mosaic-like and varied the spatial structure of a forest plantation, the more species can establish their ecological niches there (Brockerhoff et al., 2008; Oxbrough et al., 2012).

In general, the litter macrofauna of poplar plantations is a diffusive, undetermined system. It is difficult to attribute its dynamics to change in any particular single factor (soil texture, soil moisture, the litter capacity, density of tree, shrub and herbaceous layers). Interactions within the system are more significant for litter macrofauna than external factors (Butterfield and Malvido, 1992; Reynolds et al., 2003; Spitzer et al., 2008; Taboada et al., 2010; Brygadyrenko, 2014).

The most important group of litter macrofauna (which also significantly affects both the soil and crown horizons of ecosystems) is the Formicidae family (Slipinski et al., 2012). Ants alter plant cover both at the level of horizontal distribution of plant remains in the litter, which regulates the tempo and possibilities for seed growth, and at the level of redistribution of seeds of flowering plants (Dlussky, 2001; O'Grady et al., 2013). Apart from exerting an influence on the vegetation, ants also affect the litter macrofauna directly (Sobek et al., 2009). In artificial forests of Ukraine's steppe zone phytophages inhabit mostly the herbaceous, shrub and tree layers. 
They inhabit litter only at certain stages of ontogenesis or in extreme weather conditions. On average, phytophages make up 3-14\% of the litter invertebrate fauna for different types of poplar plantations. These are mostly steppe or habitat generalist species of the Chrysomelidae, Cicadellidae, Scutellaridae and other families (Moroz et al., 2011; Brygadyrenko, 2014, 2015a). With an increase in the number of phytophages, the number of individuals that fall

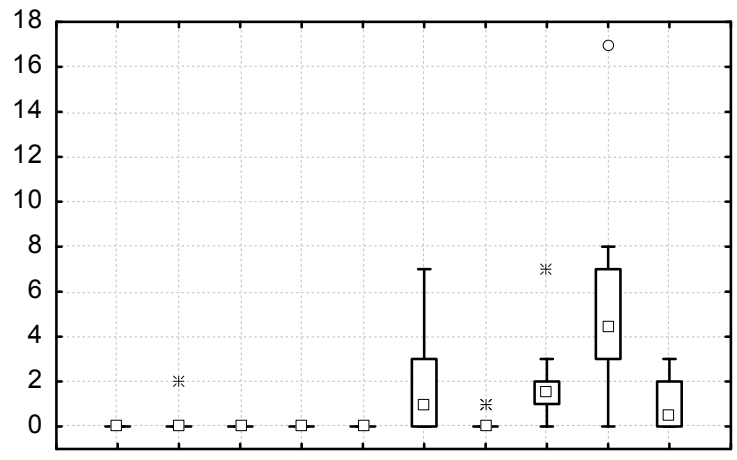

$a$

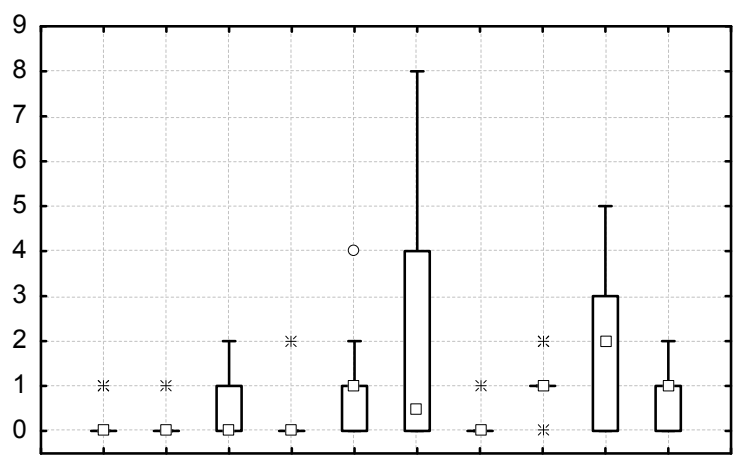

c

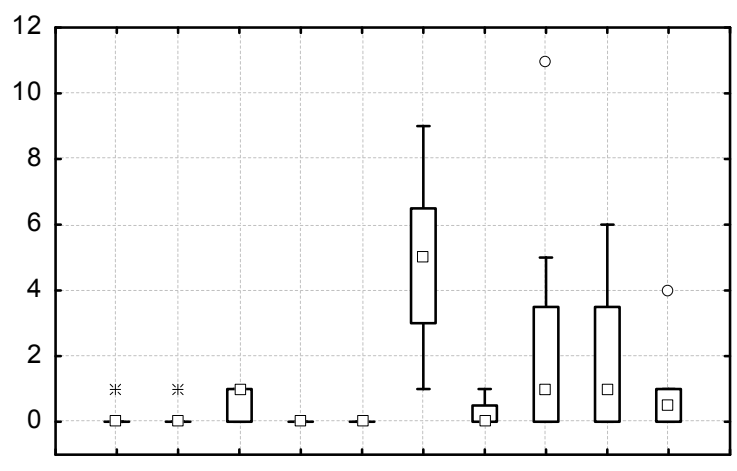

$e$

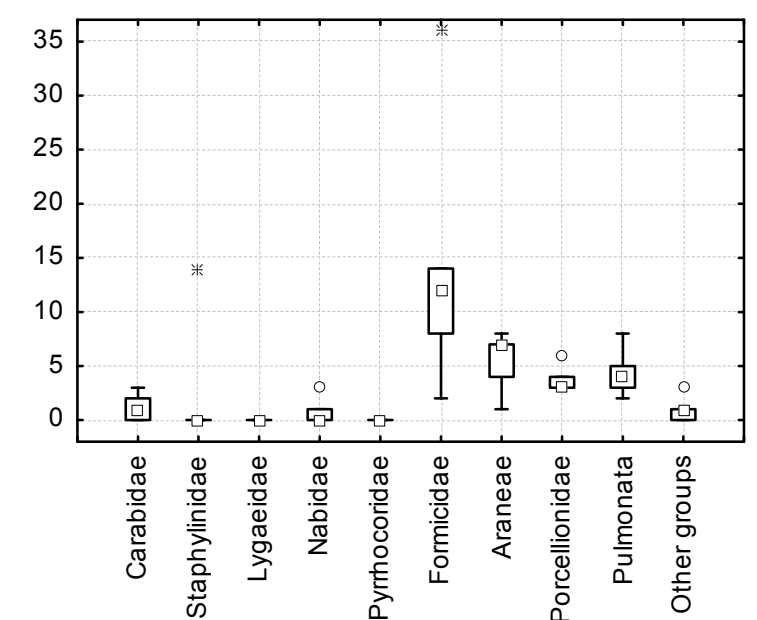

from the tree crowns and bushes onto the ground increases, providing food for litter polyphage-predators (Carabidae, Staphylinidae, Lycosidae, Thomisidae, Tabanidae larvae and others). Certain species of crown and trunk dwelling pests of poplars (Noctuidae, Tortricidae, Cossidae and others) migrate into the soil during the period of pupation, providing an additional food base for zoophages.

$b$
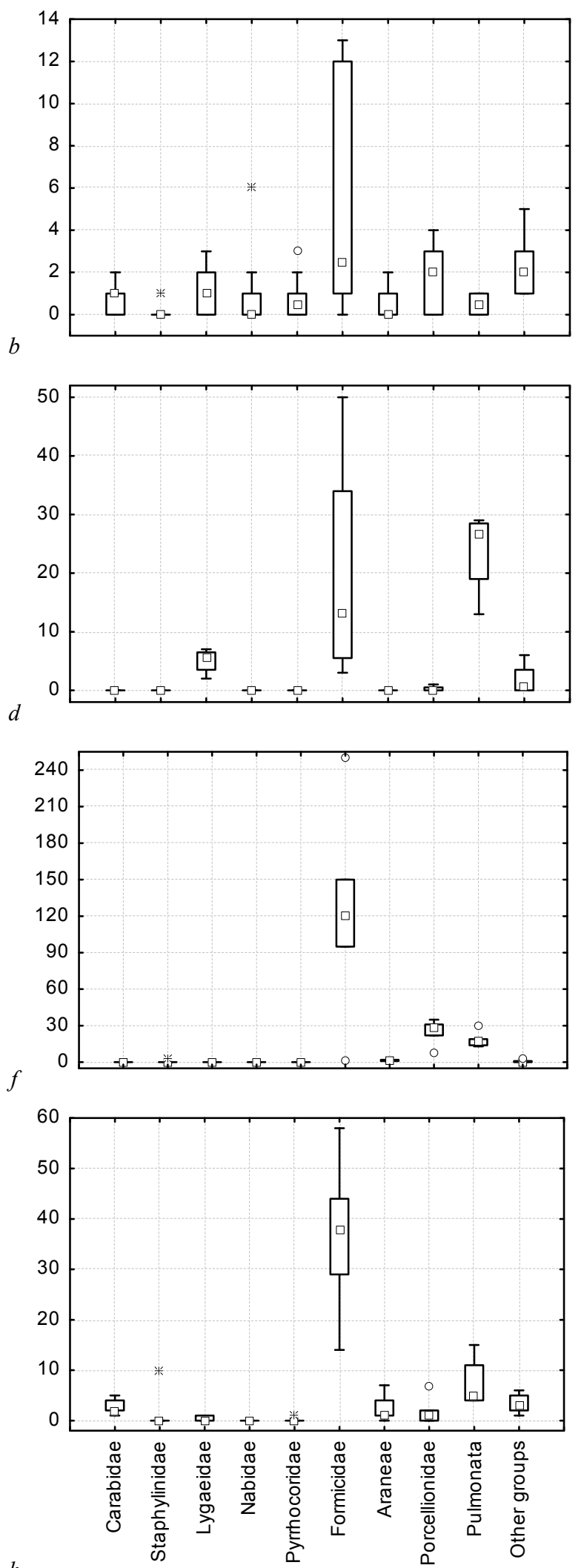

Fig. 5. Taxonomic structure of litter macrofauna of poplar plantations: $a-h$-sample plots $1-8$ (see Table 1); abscissa - dominant taxonomic group, ordinate - abundance $\left(\right.$ specimen $\left./ \mathrm{m}^{2}\right)$ 
It is highly likely, though this has not yet been proved for our region, that similar types of artificial poplar plantations outside cities will have a less impoverished and more variable compound of litter invertebrate species. We are not aiming here to assess the impact of urbanization upon the studied communities. However, in so far as urban conditions affect certain groups of litter invertebrates, it seems that under the influence of urbanization the structure of these communities is bound to be altered (Cmoluch, 1972; Kubicka, 1981; Czechowski, 1982; Crouau et al., 2002; Christian and Szeptycki, 2004; Halaj et al., 2008).

\section{Conclusion}

The species variety and complexity of litter macrofauna communities of poplar plantations can in general be characterized as impoverished and simplified compared to invertebrate communities in the plantations of most other trees. The total number of litter macrofauna of poplar plantations varies within a wide range (8-187 specimen $/ \mathrm{m}^{2}$, on average 53 specimen $/ \mathrm{m}^{2}$ ). The widest variety of species was recorded in the white poplar plantation with common hop and in the elm and poplar plantation with Amorpha fruticosa $\mathrm{L}$. and bare soil (15 and 9 species correspondingly). The Shannon-Weaver index of biological diversity reached its maximum for the abovementioned plots, at 3.2 and 2.9 bits respecttively. The largest number of zoophages $(40 \%)$ was registered in the white poplar plantation with common hop. In 7 out of the 8 studied poplar plantations the same group of species comprising just over $50 \%$ of the total number of litter macrofauna species recorded in the study was found, which indicates an unbalanced dominance structure of the community. Only in 2 out of the 8 ecosystems did the share of species rare for a given ecosystem exceed $10 \%$, which indicates an absence of potential resources for renewal of the species compound in case of change in the conditions of existence in an urban ecosystem. In the size structure of poplar plantations invertebrates of 4-7 mm length dominated (44-96\%). In 5 out of the 8 poplar plantations species with a body length of over $15 \mathrm{~mm}$ were not registered, which indicates a degradation of the size structure of the communities. In the taxonomic structure of litter macrofauna the dominant group in all types of poplar plantation was Formicidae. The subdominants were Pulmonata, Porcellionidae, Lygaeidae, Julidae, Silphidae, Araneae, Carabidae, Staphylinidae.

The data obtained can be used for evaluation of the condition of poplar plantations and for increasing their ecological resilience in urban areas of the steppe zone, where they are subject to insufficient moisture.

\section{References}

Brockerhoff, E. G., Jactel, H., Parrotta, J. A., Quine, C. P., \& Sayer, J. (2008). Plantation forests and biodiversity: oxymoron or opportunity? Biodiversity and Conservation, 17(5), 925-951.

Brygadyrenko, V. V. (2014). The influence of moisture conditions on the structure of litter invertebrate communities in shelterbelt and plantation forests in southern Ukraine. Journal of Bio-Science, 22, 77-88.

Brygadyrenko, V. V. (2015a). Community structure of litter invertebrates of forest belt ecosystems in the Ukrainian steppe zone. International Journal of Environmental Research, 9(4), 1183-1192.

Brygadyrenko, V. V. (2015b). Parameters of ecological niches of Badister, Licinus and Panagaeus (Coleoptera, Carabidae) species measured against eight ecological factors. Baltic Journal of Coleopterology, 15, 137-154.

Brygadyrenko, V. V. (2015c). Vplyv umov zvolozhennja ta mineralizacii' gruntovogo rozchynu na strukturu pidstylkovoi' mezofauny shyrokolystjanyh lisiv stepovoi' zony Ukrai'ny [Influence of moisture conditions and soil salinity on structure of litter macrofauna of the deciduous forests of Ukraine's steppe zone]. Visnyk of Dnipropetrovsk University. Biology, Ecology, 23(1), 50-65 (in Ukrainian).

Brygadyrenko, V. V. (2016a). Vplyv potuzhnosti pidstylky na strukturu pidstylkovoi' mezofauny shyrokolystjanyh lisiv stepovoi' zony Ukrai'ny [Influence of litter thickness on the structure of litter macrofauna of deciduous forests of Ukraine's steppe zone]. Visnyk of Dnipropetrovsk University. Biology, Ecology, 24(1), 240-248 (in Ukrainian).
Brygadyrenko, V. V. (2016b). Evaluation of ecological niches of abundant species of Poecilus and Pterostichus (Coleoptera: Carabidae) in forests of the steppe zone of Ukraine. Entomologica Fennica, 27(2), 81-100.

Brygadyrenko, V. V., \& Ivanyshin, V. M. (2014). Vlijanie soli zheleza na massu tela Megaphyllum kievense (Diplopoda, Julidae) i granulometricheskij sostav podstilki v laboratornom jeksperimente [Impact of ferric salt on body weight of Megaphyllum kievense (Diplopoda, Julidae) and litter granulometric composition in the laboratory experiment]. Visnyk of Dnipropetrovsk University. Biology, Ecology, 22(1), 83-87 (in Russian).

Brygadyrenko, V. V., \& Nazimov, S. S. (2015). Trophic relations of Opatrum sabulosum (Coleoptera, Tenebrionidae) with leaves of cultivated and uncultivated species of herbaceous plants under laboratory conditions. Zookeys, 481, 57-68.

Butterfield, J., \& Malvido, J. B. (1992). Effect of mixed-species tree planting on the distribution of soil invertebrates. In: Cannell, M. G. R., Malcolm, D. C., \& Robertson, P. A. (Eds.) The ecology of mixed-species stands of trees, Spec. Publ. № 11. British Ecological Society, Blackwell, Oxford, 255-265.

Cameron, K. H., \& Leather, S. R. (2012). How good are carabid beetles (Coleoptera, Carabidae) as indicators of invertebrate abundance and order richness? Biodiversity and Conservation, 21(3), 763-779.

Christian, E., \& Szeptycki, A. (2004). Distribution of Protura along an urban gradient in Vienna. Pedobiologia, 48(5-6), 445-452.

Cmoluch, Z. (1972). Weevils (Coleoptera, Curculionidae) of town plants associations of Lublin. Polskie Pismo Entomologiczne, 42, 545-562.

Crouau, Y., Gisclard, C., \& Perotti, P. (2002). The use of Folsomia candida (Collembola, Isotomidae) in bioassays of waste. Applied Soil Ecology, 19(1), 65-70.

Czechowski, W. (1982). Occurrence of carabids (Coleoptera, Carabidae) in the urban greenery of Warsaw according to the land utilization and cultivation. Memorabilia Zoologica, 39, 3-108.

Dlussky, G. M. (2001). Structure of ant community (Hymenoptera, Formicidae) from an oligotrophic peat bog. Zoologicheskii Zhurnal, 80(8), 984-985.

Faly, L., \& Brygadyrenko, V. (2014). Patterns in the horizontal structure of litter invertebrate communities in windbreak plantations in the steppe zone of the Ukraine. Journal of Plant Protection Research, 54(4), 414 420.

Ferguson, S. H., \& Berube, D. K. A. (2004). Invertebrate diversity under artificial cover in relation to boreal forest habitat characteristics. The Canadian Field-Naturalist, 118(3), 386-394.

Halaj, J., Halpern, C. B., \& Yi, H. (2008). Responses of litter-dwelling spiders and carabid beetles to varying levels and patterns of green-tree retention. Forest Ecology and Management, 255, 887-900.

Kubicka, A. (1981). Scarabaeids (Coleoptera, Scarabaeidae) of Warsaw and Mazovia. Memorabilia Zoologica, 34, 145-164.

Kul'bachko, Y. L., Didur, O. O., Loza, I. M., Pakhomov, O. E., \& Bezrodnova, O. V. (2015). Environmental aspects of the effect of earthworm (Lumbricidae, Oligochaeta) tropho-metabolic activity on the $\mathrm{pH}$ buffering capacity of remediated soil (steppe zone, Ukraine). Biology Bulletin, 42, 899-904.

Maleque, M. A., Maeto, K., \& Ishii, H. T. (2009). Arthropods as bioindicators of sustainable forest management, with a focus on plantation forests. Applied Entomology and Zoology, 44(1), 1-11.

Moroz, K. O., Lygun, A. V., \& Brygadyrenko, V. V. (2011). Sezonna dynamika pidstylkovoi' mezofauny antropogenno transformovanyh ekosystem m. Dniprodzerzhyns'k [Litter mesofauna seasonal dynamics of anthropogenically transformed ecosystems in Dniprodzerzhinsk city]. Visnyk of Dnipropetrovsk University. Biology, Ecology, 19(2), 93-102.

O'Grady, A., Breen, J., Harrington, T. J., \& Courtney, R. (2013). The seed bank in soil from the nests of grassland ants in a unique limestone grassland community in Ireland. Ecological Engineering, 61, 58-64.

Oxbrough, A., French, V., Irwin, S., Kelly, T. C., Smiddy, P., \& O'Halloran, J. (2012). Can mixed species stands enhance arthropod diversity in plantation forests? Forest Ecology and Management, 270, 11-18.

Oxbrough, A. G., Gittings, T., O'Halloran, J., Giller, P. S., \& Smith, G. F. (2005). Structural indicators of spider communities across the forest plantation cycle. Forest Ecology and Management, 212(1-3), 171-183.

Pearce, J. L., \& Venier, L. A. (2006). The use of ground beetles (Coleoptera: Carabidae) and spiders (Araneae) as bioindicators of sustainable forest management: A review. Ecological Indicators, 6(4), 780-793.

Pielou, E. (1977). Mathematical Ecology. John Wiley \& Sons, New York.

Polchaninova, N. Y., \& Prokopenko, E. V. (2013). Catalogue of the spiders (Arachnida, Aranei) of Left-Bank Ukraine. Arthropoda Selecta. Supplement No. 2. KMK Scientific Press. Moscow.

Reynolds, B. C., Crossley, D. A., \& Hunter, M. D. (2003). Response of soil invertebrates to forest canopy inputs along a productivity gradient. Pedobiologia, 47(2), 127-139.

Schuldt, A., Fahrenholz, N., Brauns, M., Migge-Kleian, S., Platner, C., \& Schaefer, M. (2008). Communities of ground-living spiders in deci- 
duous forests: Does tree species diversity matter? Biodiversity and Conservation, 17(5), 1267-1284.

Shannon, C., \& Weaver, W. (1949). The mathematical theory of communication. University of Illinois Press, Urbana.

Slipinski, P., Zmihorski, M., \& Czechowski, W. (2012). Species diversity and nestedness of ant assemblages in an urban environment. European Journal of Entomology, 109(2), 197-206.

Sobek, S., Steffan-Dewenter, I., Scherber, C., \& Tscharntke, T. (2009). Spatiotemporal changes of beetle communities across a tree diversity gradient. Diversity and Distributions, 15(4), 660-670.
Spitzer, L., Konvicka, M., Benes, J., Tropek, R., Tuf, I. H., \& Tufova, J. (2008). Does closure of traditionally managed open woodlands threaten epigeic invertebrates? Effects of coppicing and high deer densities. Biological Conservation, 141(3), 827-837.

Taboada, A., Tarrega, R., Calvo, L., Marcos, E., Marcos, J. A., \& Salgado, J. M. (2008). Plant and carabid beetle species diversity in relation to forest type and structural heterogeneity. European Journal of Forest Research, 129(1), 31-45. 